University of Minnesota Morris Digital Well

University of Minnesota Morris Digital Well

$10-2018$

\title{
The Impact of Foreign Remittances on Poverty in Nepal: A Panel Study of Household Survey Data, 1996-2011
}

\author{
Udaya R. Wagle \\ Western Michigan University \\ Satis Devkota \\ University of Minnesota - Morris, sdevkota@morris.umn.edu
}

Follow this and additional works at: https://digitalcommons.morris.umn.edu/economics

Part of the Regional Economics Commons

\section{Recommended Citation}

Wagle, Udaya R. and Devkota, Satis, "The Impact of Foreign Remittances on Poverty in Nepal: A Panel Study of Household Survey Data, 1996-2011" (2018). Economics \& Management Publications. 1.

https://digitalcommons.morris.umn.edu/economics/1

This Article is brought to you for free and open access by the Faculty and Staff Scholarship at University of Minnesota Morris Digital Well. It has been accepted for inclusion in Economics \& Management Publications by an authorized administrator of University of Minnesota Morris Digital Well. For more information, please contact skulann@morris.umn.edu. 


\title{
The Impact of Foreign Remittances on Poverty in Nepal: A Panel Study of Household Survey Data, 1996-2011*
}

\begin{abstract}
Using data from the longitudinal panel surveys of 1996, 2004, and 2011, this paper examines the dynamics of foreign remittances and their impact on poverty in Nepal. The intent is to explore how foreign remittances have evolved and impacted poverty and economic well-being of households. Focusing on a consistent set of households across the three survey rounds in a balanced panel format helps examine the effect of foreign remittances with appropriate controls. Results from methodologically consistent, random-effects regressions that correct for potential attrition and heterogeneity bias support significant poverty-reducing and, more accurately, economic well-being-enhancing effects of foreign remittances especially when originating in countries other than India. This and other findings are valuable to the assessment of policies on utilizing foreign labor migration and remittances as a vehicle to reduce poverty in Nepal.
\end{abstract}

Keywords: Foreign remittance, poverty, economic well-being, Nepal, panel data.

JEL Codes: I3; J1; J6; R2.

\section{Introduction}

Nepal has experienced a rapid growth in foreign labor migration and remittances during the past two decades. The number of migrant workers employed abroad has increased tremendously, with thousands of unemployed youth leaving the country every day. ${ }^{1}$ Not every migrant worker becomes successful in finding employment as promised or expected neither does every migrant worker remit money back home. But foreign employment has been encouraged by the government even as an active labor market strategy with remittances evolving as a major source of income for households, communities, and the nation today. The size of foreign remittance income relative to gross domestic product of Nepal increased from one percent in 1995 to close to almost one-third by 2015 (World Bank, 2017). While money received in foreign remittance is sure to improve household economic well-being, to what extent this has occurred and whether or not this effect has changed over time are valid policy questions to answer for a country increasingly reliant on it.

This paper explores how foreign remittances impact poverty among recipient households by using panel data from the 1996, 2004, and 2011 rounds of the Nepal Living Standard Survey

\footnotetext{
* Authors acknowledge the valuable feedback received from two anonymous reviewers, which has helped to improve the paper greatly. The data for this analysis come from the Nepal Living Standard Surveys (crosssectional file for 1996 and panel files for 2004 and 2011) of Nepal Central Bureau of Statistics (cbs.gov.np). Data analysis codes (in Stata) are available from the authors.

${ }^{1}$ According to a government report, the absentee population - defined as living away from Nepal for at least six months - increased by 150 percent since 2001 to close to two million in 2011 (Ministry of Foreign Employment, 2014). While not all of this amounts to foreign labor migration, this report also finds that the Government of Nepal issued almost one-half of a million permits for foreign employment in 2013/2014 alone, a figure more than twice that for $2008 / 2009$.
} 
(NLSS). The goal is to provide insights into how poverty statuses and levels have changed among households during the period and how foreign remittances are linked with such changes in household poverty. While most studies of poverty in Nepal have been either qualitative or cross-sectional, this analysis expands the coverage of survey-based analyses like those of Acharya and Leon-Gonzalez (2012), Bhatta and Sharma (2006), Loskhin, Bontch-Osmolovski, and Glinskaya (2007), and Wagle (2012) to a panel and longitudinal analysis covering a period of 15 years. Given that foreign labor migration occurs more systematically than randomly, appropriate research strategies and controls are applied to mitigate the potential endogeneity and self-selection bias. Findings will be valuable to understand how households are participating in foreign labor migration and benefiting from remittances to improve economic well-being and reduce poverty, an experience widely shared across many developing countries today.

\section{Literature Review}

Foreign labor migration and remittances provide monetary as well as nonmonetary benefits to recipient countries, communities, and households. Most directly, there is ample research to support that they help improve the economic well-being of recipient families and reduce poverty (Adams, 2005; Adams, Cuecuecha, \& Page, 2008; Gustafsson \& Makonnen, 1993; Du, Park, \& Wang, 2005). How remittance affects household well-being, however, depends on who sends workers for foreign labor migration in the first place. Theoretically speaking, sending workers for foreign employment is a household strategy to maximize economic gains and diversify sources of income (Ellis, 2003; Rakodi \& Lloyed-Jones, 2002; Thieme \& Wyss, 2005; VargasLundius, Lanly, Villarreal, \& Osorio, 2008). The widely known push and pull factors of migration necessarily enter the equation with a lack of opportunities allowing households to send their members for foreign employment (IOM, 2010; Massey, Arango, Hugo, Kouaouci, Pellegrino, \& Taylor, 1998). The economics of labor migration postulates that the decision to seek foreign employment depends on the rational calculation of risks and benefits (Stark, 1991; Stark \& Bloom, 1985).

Household members make the decision to seek foreign employment collectively since the payoffs go to the entire households. This notion of collective decision applies to almost all cases of migration as the necessary preparation requires significant investment of time, energy, and resources. To what extent one has access to information on the process of migration as well as other networks and social contacts needed to succeed during and after migration are also important (MMN \& AMC, 2012; Thieme, 2006; Wagle, 2012). Migrant workers often go through complicated legal processes both at home and in destination countries, with illegal migrants facing more daunting challenges in travel, at work, and in daily lives (MMN \& AMC, 2012; Mon, 2010; Brees, 2008). Given that the degree of preparation and investment increases with the expected payoffs, households with poor, rural, and illiterate backgrounds often cannot afford to send their members to countries or regions that offer higher employment payoffs (Cohen, 2005; de Haan, 1997; Latapi, 2012; Wagle, 2012). Because the extent to which the poor participate in foreign labor migration and remittances depends on maturity of the migration 
process, the history of labor migration affects the way benefits of remittance reach the poor. Wagle's (2012) study shows that the benefits of foreign migration and remittances may go disproportionately to those with significant financial assets.

There is no denying that remittance incomes increase the purchasing power and help improve the economic security of recipient households. A growing body of research focusing on microdata supports the livelihood strategy hypothesis in that the most fundamental reason that households send their members for foreign labor migration is because they can remit money to support the members at home (Adamsn, 2005, 2011; Adams et al., 2008; Du et al., 2005; Gustafsson \& Makonnen, 1993; Kageyama, 2008). While research conducted by Airola (2007) in Mexico shows the share of food in total consumption to be significantly lower and that of durables, health, and housing to be significantly higher among households with remittance, this is also a sign that remittance helps increase expenditures in basic necessities especially for nonfood consumption. The increased income from remittance is also shown to provide important safety net and to reduce food insecurity, something that remains precarious in much of the least developed world including Nepal (Cohen, 2005; Lacroix, 2011).

A large body of studies using micro and macro data also supports this poverty-reducing effect of foreign remittance. Adams (2011) and UNCTAD (2011), for example, have found a 10 percent increase in foreign remittance to reduce poverty by up to four percent. Even when remittances are not large enough to lift households out of poverty, they help lessen the degree of poverty experienced (Vargas-Silva, Jha, \& Sugiyarto, 2009; Wagle, 2016). Focusing on the NLSS survey data from Nepal, Acharya and Leon-Gonzalez (2012) find that remittances decreased poverty headcount ratios by between two and eight percent during 1996 and 2004, with even larger reductions in the depth of poverty. Lokshin et al. (2010) also show that migration (internal and foreign) helped reduce poverty by almost 20 percent between 1995 and 2004 in Nepal. Although the specific observation depends on the timeframe as well as other forms of reference - poverty definition and internal vs. foreign remittance, for example - it is almost unequivocal that remittances have had important poverty-reducing effects in Nepal.

How significant is this poverty reducing impact of remittance? The poverty reducing impact can sustain longer only if households manage to invest in business, agriculture, or other income generating activities. For one, the very high rates of expenditures (up to 90 percent) in basic necessities out of remittance money undermine any investment prospects (Airola, 2007; Turnell, Vickary, \& Bradford, 2008). While a comprehensive review of literature on the role of remittance conducted by de Haas (2007) in Mexico points to an important multiplier effect of increased consumption spurred by remittance at a broader level, there is no more than anecdotal evidence that remittance money has been put to productive use especially by households that are concerned with making daily ends meet. Similarly, the value added that remittance provides to poverty reduction must heed the possible displacement of existing economic activities by household members once they start receiving remittance (Adams, 2011; Latapi, 2012). Although remittance receiving families may witness increased incomes and consumption, Wagle's (2016) study from Myanmar shows that the role of remittances on economic security may be more 
limited when household characteristics relevant to determining labor migration and remittances are fully controlled. The real distinction may be in terms of the short-term versus long-term benefits of remittances, the latter of which are not easy to track through household surveys.

\section{Hypotheses and Data}

Exploring the impact of foreign remittances on poverty is highly challenging to say the least. Directly, the additional monetary resources received in remittance would help increase household incomes and consumption and reduce poverty. This suggests that foreign remittance would have significant positive impact on income or consumption and a significant negative impact on poverty. This does not mean, however, that remittances come without cost. Given the necessity of financial and nonfinancial investment to make foreign labor migration a reality, for example, the resource base may be significantly drained when households decide to send members for foreign labor migration. In some cases, emigration of some members also means that households receiving foreign remittance may cut down on their income generating activities at home. The flip side can be that households are able to invest the extra resources from remittance on activities that generate further returns especially when we consider a longer time span. But the most fundamental impact of labor migration is that the emigrating member's potential to generate income at home, otherwise known as the opportunity cost, would be necessarily lost as a result of migration. While the poverty-reducing hypothesis of foreign remittance still holds since the payoff of foreign employment can be significantly higher than what would be possible otherwise, this complexity suggests that the outcomes can be quite different when multiple factors are incorporated. To the extent that these opportunity costs can be incorporated, the hypothesis of poverty-reducing effects of remittances may not fully hold. This is also precisely the issue this analysis explores more fully in the temporal context of Nepal.

The data for this analysis come from three rounds of the Nepal Living Standard Survey (NLSS): 1996, 2004, and 2011. While the typical usage of NLSS data has focused on the close to 3,000 households included in its independent, cross-sectional samples, the focus here is on the panel version. To clarify, data come from the 1996 cross-sectional survey of over 3,000 households (there was no separate panel sample in this first round), followed by samples of about 1,000 each from the 2004 and 2011 rounds. A total of 752 households from the 1996 sample were interviewed in 2004 and a total of 780 households interviewed in 2011 came from the 1996 or 2004 samples. But only 434 households were tracked consistently across the first, second, and third rounds of the survey, making this the effective sample size for the balanced panel analysis. ${ }^{2}$ Given that the balanced panel yields a sample size that is significantly smaller (58 percent of those interviewed in 1996 and $2004^{3}$ ), a side-by-side comparison of results using the full panel

\footnotetext{
${ }^{2}$ Additional notes on the sampling design and its representation are provided in YYY (XXXX). The Central Bureau of Statistics that is responsible for designing and conducting these surveys provides reports and publications on the data and technical issues (CBS, 1996, 2004, 2011a).

${ }^{3}$ Since the 1996 cross-sectional sample was used as the starting point for the 2004 sample, computing attrition from the 1996 sample does not make complete sense. It is also noteworthy that the panel of households is
} 
samples is also presented, when appropriate.

Data are also needed on foreign remittances, poverty, and other relevant characteristics of households as well as household heads (or simply "householders"). Foreign remittances are measured in terms of the presence or absence as well as the value of cash or non-cash receipts from foreign countries with further breakdown into India and others as the source countries. Poverty is measured in terms of poverty status as well as the poverty or, more precisely, nonpoverty level of households by comparing their consumption expenditures relative to the applicable nationally defined poverty lines, detailed by geographies and household sizes for the given years. ${ }^{4}$ Household and householder characteristics including geography, education, occupation, and other demographics are used to enrich the analysis by helping to predict the status and level of poverty more accurately.

\section{Changing Remittance Rates}

Data summarized in Table 1 indicate that slightly over 10 percent of the sampled panel households had foreign remittances in 1996, with this number remaining virtually unchanged by 2004. But interestingly, this number declined, quite significantly, to under five percent by 2011. These numbers are also consistent between the panel and balanced panel data, with the latter focusing on the same 434 households surveyed across all three episodes. The only exception is 2004 in which the remittance rate for the balanced panel declined by about two percentage points. What is interesting is the source of this foreign remittance with nine out of 10 households receiving remittance from India in 1996, which ratio declined quite drastically to three out of 10 by 2004 . By 2011, however, this ratio increased to over six out of 10 even though the actual rate of remittance was more than halved from that of 2004.

(Table 1)

It is important to remember that these remittance rates do not fully capture the rate of foreign labor migration which is growing enormously in Nepal. For one, some of these households receive remittance from multiple members whereas some labor migrants may not remit money at all. These data are also not fully comparable with other findings which show growing rates of foreign remittance in Nepal. While the data used for 1996 are identical, the almost 18 percent rate of foreign remittance found by Wagle (2012) emanates from the cross-sectional sample of

formed from the raw data for each survey year by merging records of all members with the given unique household identifiers, without any attention to the potential splits, mergers, or other structural circumstances. ${ }^{4}$ This involves aggregating different categories of expenditure including for food, house rental, utilities, and other nonfood items (using the standard 30-day recall period) at the household level. Food items include food consumption through purchase, in-kind receipts, or home-grown produce. Non-food items also have similar sub-categories. Owner occupied housing signifies the value of house rental or forgone income. Other expenditure items including education and health care are not included because of the complexities in their valuation as some of it is received publicly whereas others are purchased in the private market. While this analysis does not fully replicate the computations of the CBS (1996, 2004, 2011a), estimates are somewhat comparable and internally consistent. See YYY (XXX) for detailed comparison of the computations and their results. 
the 2004 survey. Even more importantly, the fact that households with foreign remittance are likely to move either to urban areas or even internationally makes it challenging to obtain panel samples for over a decade that is fully representative in terms of their labor migration. As important as maintaining representative samples is the ability to track the consistent of set of households in terms of their patterns in labor migration and remittances (as well as poverty).

But what is the pattern of foreign remittances among the sampled households? Figure 1 shows that the rate of foreign remittance among the 434 households included in the balanced sample has declined consistently over time. Whereas 90 percent of the households did not receive foreign remittance in 1996, only 10 percent of them received it in 2004. Of this smaller group, moreover, none received remittance about seven years later. While six percent of the households without foreign remittance in 2004 did receive it in 2011, this as well as the zero rate of remittance in both 2004 and 2011 among households receiving remittance in 1996 help explain how foreign remittance may have indirectly caused many households to be out of the panel sample.

(Figure 1)

\section{Poverty Incidence and Its Interface with Remittance}

Table 2 presents the estimates of poverty for households and their changes over time using the full as well as balanced panel samples. Data from the full panel suggest that over 58 percent of the households were in poverty in 1996 with this figure declining by 20 percentage points by 2004 and yet increasing by another six percentage points by 2011 . While the combined poverty rate stands at over 55 percent for the entire period, this is bit deceptive because of its bias toward the much higher rate applicable to 1996 with over 3,000 households. The specific methodology applied to compute household consumption can lead to very different poverty estimates as well. ${ }^{5}$ What is clear, however, is that almost one-half of the population may still be living in poverty despite significant declines shown by many reports and publications.

\section{(Table 2)}

Estimates from the balanced panel of 434 households show somewhat lower rates of poverty especially for 2004, with the overall poverty rates declining to just over 41 percent given the exact weighting of data across the three surveys. Since households included in the panel samples vary over time, the message from the estimates focusing on the balanced panel is that poverty incidence has indeed fluctuated across the three survey years with significantly lower incidence in 2004. While the use of revised poverty lines for 2011 may have resulted in a slight increase in poverty incidence for 2011 (CBS, 2011b), it is fair to conclude that reducing poverty has been an enduring policy challenge in Nepal.

\footnotetext{
${ }^{5}$ The cross-sectional version of the NLSS data have shown that poverty headcount ratio declined from 42 per cent in 1996 to 31 per cent in 2005 and then to 25 per cent in 2011 (CBS, 2011b). The magnitude as well as the temporal decline also vary depending on the specific methodology, with some reports showing the poverty rates of 35 and 33 percent for 1996 and 2004 respectively (Bhatta \& Sharma, 2006).
} 
Table 2 also provides estimates useful to link poverty with foreign remittance. Before getting into that, however, it is important to observe the changing poverty spells among the 434 households included in the balanced panel across the three survey years. Figure 2 shows that, of the 58 percent that were poor in 1996, 42 percent remained poor whereas the remaining 58 percent exited from poverty. Of those exiting the poverty spell in 2004, however, about 42 percent descended into poverty again whereas 58 percent remained non-poor. This breakdown flips among households that remained poor in 1996 as well as 2004, with 60 percent of them still poor by 2011. The rate of poverty is much lower at 21 percent among households that were found to be poor in 1996. While households that were consistently non-poor in 1996 and 2004 had slightly higher poverty rates (27 percent) in 2011, 43 percent of those who descended into poverty by 2004 were stuck there as of 2011 as well. This description paints a picture of longerterm, structural, and perhaps intergenerational poverty in which current poverty status largely determines the poverty status at some future date (Carter \& Barrett, 2006). But this also supports the transient nature of poverty in which there is at least 20 percent chance that even the non-poor households enter into poverty later in life (YYY: XXXX).

(Figure 2)

To come back to the link of poverty with foreign remittance status, Table 2 makes it clear that poverty rates are almost indistinguishable between households with or without remittance as well as across the different source countries. To be precise, there are observable differences with households with foreign remittance especially from India experiencing significantly greater poverty rates in general as well as in 1996. But this poverty increasing-impact or link of foreign remittance flipped by 2004, which by 2011 became either indistinguishable (for the full panel sample) or reverted almost to the levels of 1996 (for the balanced panel sample). A positive way of interpreting this is to suggest a lack of evidence to link poverty with remittances, which may in part have resulted from a small rate of remittance recipiency $(<11 \%)$. This may also mean, however, that it is the relatively poorer households that tend to participate in foreign labor migration which does not always deliver its promise of large payoffs especially in case of seasonal jobs in India (Thieme, 2006; Wagle, 2012).

\section{(Table 2)}

How do these poverty rates vary in relation to foreign remittances temporally? Table 3 presents a two-way interface of the poverty and foreign remittance status for all three survey years. Over 24 percent of the households were never poor whereas over 77 percent of the households never received foreign remittance. At the opposite end of the spectrum were close to 15 percent of the households that were poor across all three episodes even though their foreign remittance status varied. While the primary motivation in this paper was to identify who has always been poor and/or received remittance, none of the households included in the survey was actually a repeat remittance recipient - meaning that the latter two surveys exhibit complete attrition of households receiving foreign remittance at an earlier period. ${ }^{6}$ But the fact that the

\footnotetext{
${ }^{6}$ The sample is seemingly biased with respect to the status on foreign remittance, owing perhaps to the apparent reason that all of the remittance receiving households moved and thus were not captured in the
} 
balanced panel samples can be divided into those that never received remittance $(77 \%)$ and those that received remittance in different years-1996 (10\%), 2004 (9\%), and $2011(4 \%)$-is still useful because their poverty status can be examined further. Of the households without foreign remittance, for example, 16 percent were always poor, 25 percent were never poor, 33 percent were poor during only one survey year, and 26 percent were poor during two of the three survey years. Of those with foreign remittance, moreover, 11 percent were always poor, 21 percent were never poor, 32 percent were poor during one survey year, and 35 percent were poor during two of the three survey years. While the rates of poverty varied across survey years, the prime take away from this exercise is that those without remittance tended to exhibit persistently higher poverty spells and yet significantly lower rates of poverty across two of the three survey years.

(Table 3)

It is important to remember that none of this discussion focuses on differences in the degree or severity of poverty experienced across households without or with foreign remittance. Figure 3 displays the median non-poverty levels ${ }^{7}$ for the poor and non-poor across the two groups of households as generated from the full panel and the balanced panel. Admittedly, these profiles are highly aggregated and rudimentary given that the data come from three survey years only. These may also be less consistent for non-poor households especially when they are generated from the full and more heterogeneous panel samples, which include a combination of highly diverse cases even though the median non-poverty level is expected to claim some stability. But the profiles are so consistent on the side of poor households that the median poverty level among households with remittance actually improved, even surpassing those of the poor, non-remittance recipient households by 2004 and especially 2011 . While the median non-poverty levels of nonpoor households changed more drastically especially in case of the larger panel samples, there is still evidence that remittance receiving households witnessed even more drastic improvement in their median consumption levels. Starting with much lower levels of consumption than their counterparts without remittance in 1996, household remittance proved to be highly beneficial over time.

(Figure 3)

\section{The Model}

\footnotetext{
following surveys. This does not necessarily mean, however, that the samples were biased because the representativeness was maintained in other respects by adding other households (CBS, 2011a). YYY (XXXX) provides further examination of the representativeness of the samples using similar panel data.

${ }^{7}$ This is measured as consumption relative to the household need expressed in the applicable poverty line so that higher values indicate better off positions for both poor and non-poor households. For example, the value of 90 signifies a 10 percent shortfall of consumption whereas a value of 190 signifies a 90 percent surplus (or better off position) of consumption. Overall, this can be interpreted as consumption as a percentage of the poverty or non-poverty level.
} 
While the above two-way analysis is insightful, a multivariate model of poverty is needed to examine the specific role of remittance vis-a-vis those of other important household characteristics that collectively determine the production function of poverty and economic wellbeing of households. The generic production function of poverty or economic well-being, $Y$, takes the following form:

$$
Y_{i t}=\beta_{0}+\beta_{1} x_{i t}+\beta_{2} z_{i t}+\varepsilon_{i t} \quad \ldots \quad \ldots \quad \ldots \quad \text { (1) }
$$

Where $X$ represents remittance; $z$ represents the vector of geography, human capital, and other household characteristics; and $i$ and $t$ represent households and years of survey respectively. Household characteristics making up the composition of households as well as key demographic features of householders signify an important element of the production function as they determine both capacity and need of households to engage in various economic activities. The theoretically significant aspects of these household characteristics include such sociodemographic features as caste and ethnicity as well as household size, number of members under 18, and gender, age, and marital status of householders (YYY, XXXX; World Bank \& DFID, 2005; World Bank, DFID, \& ADB, 2006). Prime indicators of human capital with theoretically strong predictive powers for poverty and economic well-being include education and occupation especially of householders (Bhatta \& Sharma 2006; Karki \& Bohara 2014; Wagle 2015). Given that households derive an important part of economic well-being from their endowments, household property ${ }^{8}$ is also an integral element of the household characteristics (Carter \& Barrett, 2006; Carter \& May, 2001; YYY, XXXX). Furthermore, geographic features including urban/rural locations as well as regions and ecological belts either facilitate or constrain the productive capacity of households to derive economic well-being and poverty (Cohen, 2005; Latapi, 2012; Wagle, 2012).

More focal to this analysis, however, are the roles of foreign remittances in determining poverty after controlling for the above factors. Remittances can have different forms of measurement including their presence and magnitudes with further breakdowns by the source country especially in reference to India versus other third countries. Given that economic wellbeing can be more accurately characterized in terms of poverty status as well as the level of nonpoverty (or poverty if the measure is under 100), different versions of this production function will be estimated.

The issue of sample size is also important as it affects the specific methodology applied to estimate this generic model. It is noteworthy that the full panel samples have much wider coverage from which balanced panel samples are created. To be consistent with the motivation of examining the role of remittance on poverty over time, however, this part of the analysis focuses on data from the balanced panel only. While the sample size would be more limited and the data do not include households receiving remittances during multiple survey years, ${ }^{9}$ the

\footnotetext{
${ }^{8}$ This includes all forms of assets with value such as land, houses or buildings, durable goods and equipment, net worth of businesses, livestock, and other cash and non-cash holdings.

${ }^{9}$ Important to keep in mind is that this would not be any different in case of the full panel samples since the additional households do not even repeat.
} 
balanced panel still allows proper examination of multiple poverty spells to address some of the potential endogeneity problems inherent in situations like this ${ }^{10}$ (Adams, 2011). Even in terms of the representativeness of different population groups, the balanced panel households are not significantly different from the larger panel households in the rates of poverty and remittances. Although Janajatis, urban locations, Hills and Terai areas, and households with older, male householders have somewhat lower representation (YYY, XXXX), the fact that this applies mostly to the 2011 survey introducing a large number (over 50\%) of new households, suggests that the population dynamics may have also changed over time.

Methodologically, since the data include time-varying measures of household characteristics, the potentially "more consistent" fixed-effects panel data regressions would throw away information that would be helpful to explore rival explanations. Many of these time-invariant variables including caste and ethnicity, urban locations, Hills and Terai areas, and development regions are also shown to exert significant impact on economic well-being and poverty in Nepal as well as elsewhere (Bhatta \& Sharma, 2006; Cohen, 2005; Karki \& Bohara, 2014; Latapi, 2012; Wagle, 2015; World Bank \& DFID, 2005; YYY, XXXX). While the choice of fixed versus random effects regressions is typically settled empirically (for example, by using Houseman tests), Bell and Jones (2015) and Wooldridge (2009) suggest this to be directly linked with the purpose of analysis with the random effects regressions incorporating more detailed information. This analysis therefore focuses on the random effects regressions of poverty status (Logistic) as well as non-poverty levels. The goal here is to ascertain the extent to which foreign remittances play a role in determining the poverty status or level among households after controlling for a comprehensive set of household characteristics. But this approach, in and of itself, does not fully account for the potential self-selection and attrition bias even while using random survey data. Because households continuing into the panel samples as well as those receiving foreign remittance are self-selected depending on a variety of reasons that go beyond what can be captured in these data, the assumption of equal probability sampling and exogeneity of remittance may not fully hold (Adams, 2011).

Two separate strategies are adopted to address these concerns. The first involves weighting random effects models by the "inverse probability" of attrition following the approach developed and applied by Fitzgerald, Gottschalk, and Moffitt (1998) based on the work by Becketti, Gould, Lillard, and Welch (1988). While the bias resulting from attrition of over 40 percent of the households cannot be removed in its entirety, this adjustment is useful to compare results across different model variations by mitigating the bias associated with a potential for systematic attrition. Operationally, this process requires creating a weighting factor from the predicted probabilities of attrition between the unrestricted and restricted models:

$$
A_{i}=\gamma_{0}+\gamma_{1} x_{i t}+\gamma_{2} z_{i t}+v_{i} \quad \ldots \quad \ldots \quad \ldots \quad \text { (2) }
$$

\footnotetext{
${ }^{10}$ An alternative to the balanced panel analysis would be an unbalanced panel analysis expanding the sample size quite significantly (1,304 vs. 5,369). But this is not pursued since, in addition to expanding the length of the paper substantially, this alternative would have biased the results toward the "attriters" or "new panel entrants," effectively moving the analysis and findings away from its central premise.
} 


$$
A_{i}^{*}=\delta_{0}+\delta_{1} x_{i t}+e_{i} \quad \ldots \quad \ldots \quad \ldots \quad \text { (3) }
$$

Where, $A_{i}=1$ if the household is an attriter and 0 otherwise; $x$ is the vector of core explanatory variables including presence of remittance, consumption per capita, and property-holding per capita; and $\mathrm{z}$ is the vector of auxiliary, and typically demographic, variables. The weighting factor, $W_{i}$, then is the ratio of the predicted probabilities of attrition between equations (3) and (2) $\left(p_{r} / p_{u}\right)$ estimated using Probit regression. It is also important to note that since the panel dataset formalized in 2004 begins with 752 households interviewed in both 1996 and 2004, the subscript $t$ refers to 2004 (or year 2) with $A_{i}=1$ for households interviewed in both 2007 and 2011 and 0 otherwise. The model outlined in equation (1) is then estimated with $W_{i}$ as the weighting factor (i-weight in Stata) in order to arguably remove the potential attrition bias. In addition, equation 2 is used to ascertain the degree to which attrition bias is operational in the balanced panel data.

Second, the models of poverty level and status apply the "within-between formulation" of Bell and Jones (2015) in order to correct for any potential correlation between covariates and residuals. By drawing from prior work by Mundlak (1978), Bell and Jones (2015) adjust the random model intercepts by adding a between-effect term which helps to model the heterogeneity bias associated with time varying covariates. Beginning with the following unadjusted random effects operation from equation (1), the adjusted model takes the form:

$$
Y_{i t j}=\varphi_{0}+\varphi_{1}\left(X_{i t j}-\bar{X}_{t j}\right)+\varphi_{2} \bar{X}_{t j}+\varphi_{3} z_{i t j}+u_{i t j} \quad \ldots \quad \ldots \quad \ldots \quad \text { (4) }
$$

Where, $i, t$, and $j$ represent households, years of survey, and remittance status respectively. The

group means, $\bar{X}_{t j}$, and the variables adjusted by group means, $\left(X_{i t j}-\bar{X}_{t j}\right)$, help separate the between- and within-effects, without risking collinearity caused by extended heterogeneity. In this equation, $\varphi_{1}$ captures the impact of the temporary deviations of $X$ from its mean (within effect) whereas $\varphi_{2}$ captures the impact of a permanent component of $X$ (between effect). Additionally, just like the fixed-effects estimator, this approach assumes there are no timevarying omitted variables that are correlated with the covariates used in the model. But it is this ability to model higher level entities (e.g., those with or without remittance, different castes and ethnicities, and different locations) that lead Bell and Jones (2015) to conclude in favor of using random effects models even when a Hausman test would suggest in favor of using fixed-effects regressions for greater consistency.

\section{Results}

Table 4 presents results from the panel data Logistic regressions of poverty status. While poverty status as the dependent variable remains unchanged, the model specifications change with regard to the use of foreign remittances in aggregate, remittances from India, and those from countries other than India as dichotomous variables and the amount of foreign remittance received as a continuous variable. The models perform reasonably well with a moderate power to accurately predict fraction of the poor and non-poor status of households. The role of household property is consistently significant and negative as are those of education and urban areas as they help lower the likelihood of poverty. Few other household characteristics also exhibit consistently 
significant coefficients even though their impacts on the likelihood of poverty are positive: Janajati ethnicity, far-western region, and the number of household members under 18.

(Table 4)

The coefficients on foreign remittance are mostly insignificant with only that from countries other than India showing significant coefficient at 90 percent confidence level. Whereas the impact of foreign remittance measured as the presence of it as well as the actual amount received is negative, this does not turn out to be significantly different from zero. Particularly interesting is the insignificant and even positive association of foreign remittance from India with poverty status since the relatively smaller amounts of remittance received from this mostly seasonal form of labor migration may not have been large enough to significantly change the likelihood of poverty. If anything, the presence of remittance from countries other than India may have helped reduce poverty.

It is important to note that these results focus exclusively on poverty status, without distinguishing the degree of non-poverty experienced by households. The results presented in Table 5 measure the dependent variable in terms of the economic well-being of households that are relative to the needs as operationalized in the applicable poverty line. Given that non-poverty level has continuous measurement and the covariates include many key time-invariant variables, this model is estimated as a random effects regression with maximum likelihood estimator in the panel data framework. The explanatory powers of these models are not very high which is consistent with the significance of few covariates as well. In fact, while the coefficients of some variables, significant from the model of poverty status (Table 4), turn out to be insignificant here, some similarities also exist especially with regard to household property and urban areas.

(Table 5)

The focus on non-poverty level helps examine the role of foreign remittance more clearly. Whereas the coefficient of the presence of remittance from India is still insignificant, the amount of foreign remittance as well as the presence of remittance from countries other than India have highly significant and positive coefficients. This suggests that remittance from third countries makes significant contributions ( $327 \%$ of the applicable poverty line) to increasing consumption relative to the household need. In fact, the size of this contribution is quite substantial: having remittance from third countries can bring household consumption from zero to well above the applicable poverty line, with other factors held constant. This also holds true for the amount of foreign remittance with about an additional NRs. 25,000 (or US\$ 350 in 2011 exchange rate) of remittance helping to lift an average household out of poverty. While this poverty-reducing impact of remittance also applies to the presence of foreign remittance itself without any distinction between India and third countries, the level of confidence declines to close to 90 percent.

The next step in the process is to continue with the random effects regressions but yet adjust the models to address potential attrition bias. While the formal test following equation (2) 
effectively rules out the prevalence of attrition bias, ${ }^{11}$ the corrective measures proposed by Fitzgerald et al. (1998) are adopted to address any potential issues given the relatively high rate of attrition. Table 6 reports outcomes from the panel data models after arguably purging this attrition bias by using the inverse probability of attrition computed following equations (2) and (3) as the weighting factor. Results not only support the relevance of adjusting models where high attrition remains a major issue as the model fits indicated by the measures of likelihood ratio test improve significantly. The impacts of foreign remittance after correcting for attrition bias also turn out to be larger and more significant across all forms of measurement. The role of foreign remittance in particular becomes significant at a higher ( 95 percent) level, affording greater confidence in rejecting the hypothesis of no association.

(Table 6)

The next set of outcomes reported in Table 7 continues with the random effects and Logistic models of poverty but following the between-within formulation of Bell and Jones (2015) to control for any potential correlation between covariates and residuals. To be clear, this exercise focuses on the groups with and without remittance by year with the amount of remittance averaged and subtracted for those with remittance across the different panel years for use with the averages themselves to capture the within- and between-effects. While the outcomes from the estimation of equation (4) are not highly sensitive to these adjustments, separating the impact of foreign remittance between and within groups helps improve the model performance as well with the percentage of poor and non-poor accurately predicted by the Logistic model increasing from 66 to 68 (result not reported). The random effects regression shows that both of the between- and within-effects of remittance recipiency significantly affect the non-poverty level of households with higher levels of remittance helping to increase consumption relative to the poverty line. This poverty-reducing impact of remittance is also reaffirmed by the significant negative coefficient of mean-differenced measures of remittance shown by the Logistic regression, even though this result is not supported in case of between-effects.

(Table 7)

While these techniques provide an insight into how foreign remittances have directly impacted the economic well-being and poverty status of households, they do not fully account for the differences in economic well-being that go beyond these observable characteristics. The opportunity cost as well as other indirect costs and benefits of foreign labor migration suggests that regressions alone may not fully capture the impact of remittance. Particularly important is the need to use counterfactuals across households with and without remittance so that the impacts of foreign labor migration with respect to the relative advantages and disadvantages can be examined. The final component of this analysis includes Blinder-Oaxaca decompositions that apply counterfactuals or conditions of a specific group to estimate the unexplained variation that would be attributable to belonging to the group of remittance receiving households. The idea is

\footnotetext{
11 The difference in attrition was found significant (95\% level) for MCH caste and agriculture and forestry and production occupations of householders, with differences by property holding and Hills region showing marginal significance ( $90 \%$ level). More importantly, the roles of foreign remittance and household consumption were not significant neither were any other cross-sections.
} 
to apply the production function regression models developed and estimated above (equation 1) to identify the relative advantages and disadvantages of remittances in terms of the level of nonpoverty. Although the original Blinder (1973) and Oaxaca (1973) procedures were developed for linear regressions, the technique developed by Sinning, Hahn, and Baur (2008) can be applied to non-linear situations as well. ${ }^{12}$

Results reported in Table 8 suggest that close to 50 percent of the variations in non-poverty level is explained by the productive characteristics or endowments included in the production function. The difference in unexplained variations in the degree of non-poverty with the given covariates are about one-half between households with and without foreign remittance. In fact, this relative difference amounts to 44 percent when all sources of foreign remittance are included, with further breakdowns into remittances received from India as well as other third countries exhibiting this unexplained variation close to 50 percent. These results may have been affected by very low rates of remittances, going to as low as two and one-half percent especially for India and other third country sources. It is also noteworthy that not all of the unexplained variation may be attributed to foreign remittances since the actual process by which economic well-being is determined goes beyond what can be captured in the production function used here. For example, self-selection as well as other individual factors speaking for hard-work, motivation, and capacity to remit money can be important sources of such unexplained variation. But the fact that remittances account for close to one-half the variations in economic well-being speaks for the relatively large roles of foreign labor migration among households in Nepal.

(Table 8)

\section{Discussions and Conclusion}

In the context of growing foreign labor migration and remittances, this analysis offers insights into the way foreign remittances have impacted poverty and economic well-being among households in Nepal. The survey data used in this analysis are by no means representative of the entire population. Whereas the panel samples that are redesigned by the CBS at every iteration of the NLSS may not be fully representative, unlike their larger cross-sectional counterparts, the balanced panel versions of the data yield even more limited coverage. While estimated to be close to seven percent in 2011 (Department of Foreign Employment, 2014), the prevalence of foreign remittances is also difficult to ascertain. But it may actually be much higher than five percent (or lower) that is identified from the 2011 version of the data used here. This analysis may not have fully represented the recent dynamics of foreign labor migration and remittances in Nepal. At the same time, even though certain ethnicities are found to have higher (LCH) or lower ( $\mathrm{MCH}$ and Newars) rates of attrition, more uniform representation exists across other demographic breakdowns (YYY, XXXX). The exclusive focus on the balanced panel households consistently tracked across 1996, 2004, and 2011 causes some loss in representation with regard to households receiving foreign remittances as they are more likely to move. The political

\footnotetext{
${ }^{12}$ Additional complexity of applying this procedure to the panel data is addressed by using cluster-robust standard errors by the year of survey, which albeit not ideal accounts for temporal deviations.
} 
instability and personal insecurity associated with the decade-long Maoist insurgency from the mid-1990s may have also affected the self-reported estimates of consumption, remittances, and other contextual factors analyzed here. But, on balance, this analysis focusing on the balanced panel data provides important insights into how foreign remittances have impacted poverty and economic well-being of households in Nepal.

Given that foreign remittances may encourage and enable households to move, their attrition from the balanced panel supports the observation that poverty rates are higher among the balanced panel households than among the full panel households. But this analysis finds that foreign remittances may not necessarily have reduced poverty rates among households, with equal or even greater rates of poverty among those with foreign remittance. The issue of attrition can be so prevalent that the data do not include households with foreign remittance across two of the three years surveyed, let alone across all three years. Yet, the relatively lower rates of nonpoverty among households without foreign remittance increased significantly by 2011 whereas the lower rates of poverty among households with foreign remittance in 1996 and 2004 also increased significantly by 2011 . This creates a highly complicated picture of the interface of foreign remittance with poverty even though the median non-poverty level improved significantly for households with foreign remittance over time. This is consistent with the fact that while the median value of foreign remittance increased four-folds between 1996 and 2004from NRs. 10,000 to NRs. 42,000 (US\$ 142 to 598 in 2011 exchange rate) - it declined by 2011 almost to one-half that of 1996, resulting perhaps from the high rate of attrition among households with foreign remittance.

But findings from the multivariate analysis largely support the poverty reducing hypotheses of foreign remittance. To be sure, this impact specifically applies to the degree of non-poverty measuring household consumption relative to needs as defined by the applicable poverty lines with foreign remittances helping to improve economic well-being or reduce the degree of poverty significantly. Moreover, even this economic well-being-enhancing impact is more significant in case of remittances from sources other than India with the amount of foreign remittance playing even a more consistent role. While the amount of remittance as well as the presence of remittance especially from third countries are found to directly improve economic well-being, this finding remains highly stable across different model specifications and formulations including those that address the potential attrition and self-selection bias. Findings are not very compelling in case of direct poverty-reducing impact when poverty status is treated as a dichotomous variable, which apparently throws away the potentially useful information in terms of the degree of non-poverty. But the between-within formulation of Bell and Jones (2015) helps to recast this into different levels, suggesting that the actual impacts of mean-differenced measure of remittance are significant at a very high confidence level. Furthermore, while many unobserved variables may have been left out, the Blinder-Oaxaca decomposition analysis supports this poverty-reducing, or more accurately economic well-being-enhancing, impact of remittances as they help explain almost one-half of the variation in non-poverty level of households. 
Several observations stand out in terms of the contributions of this analysis. First, these findings imply that foreign labor migration especially to countries other than India may have been quite beneficial to improving household welfare and reducing poverty. In the context of growing foreign labor migration with thousands of young unemployed people - particularly men-leaving for many Gulf as well as East Asian countries, ${ }^{13}$ this analysis supports the notion that the resulting payoffs can be beneficial for their households. This also supports the extant policy framework of the Government of Nepal that underscores foreign labor migration as a strategy to address mass unemployment and poverty and seeks to streamline and institutionalize the legal process for Nepalis to seek foreign employment and emigrate (Department of Foreign Employment, 2014). Whereas this mobility does not occur without direct or indirect costs including significant opportunity costs (Thieme \& Wyss, 2005; Wagle, 2012), the widespread lack of employment opportunities especially in the countryside of Nepal elevates the potential benefits relative to the costs involved. The case of India is different since the benefits of labor migration do not turn out to be highly significant in case of this relatively low-cost, open-border destination often providing seasonal opportunities (Thieme, 2006; Wagle 2012, 2016). But this difference in destination countries also emanates from the capacity of households - in skills, finances, social contacts, etc. - to send members for labor migration to industrial countries, Gulf or East Asian countries, or India representing the potential payoff in descending order. To take this policy implication even further, the government could emphasize human capital development in order to cater to the need for skilled labor internationally.

Second, the findings of this analysis are generally consistent to those from the existing research. The exclusive focus on foreign remittance as opposed to remittance in general makes this analysis much different from many other studies (Acharya et al., 2012; CBS, 1996, 2004, 2011b; Loskhin et al., 2007; Wagle, 2012). It is also important to underscore the unique quality of this analysis focusing on the balanced panel households out of national surveys conducted in 1996, 2004, and 2011 as it may not fully align with the findings from the cross-sectional variants of this survey. In this sense, it would not be prudent to make sweeping claims about the specific magnitude of the impact of foreign remittances on economic well-being or poverty. But the conclusion that foreign labor migration - especially to countries other than India - can help improve economic well-being or reduce poverty among participating households is very consistent with evidence from the existing research focusing not just on Nepal but internationally (Adams, 2005, 2011; Kageyama, 2008; UNCTAD, 2011; Wagle, 2012, 2016). Even more important is the observation that this poverty-reducing and especially economic well-beingenhancing impact of remittances endures the test of multiple frameworks and methodological adjustments.

Third, this analysis operationalizes two separate methodological advancements that are increasingly embraced in the field of international development. Whereas researchers struggle with the best way to use the increasingly rich sets of survey data, the attempt at testing and

\footnotetext{
${ }^{13}$ Almost 1,500 per day according to some government estimates, which does not even include the easy and undocumented migration to India (Department of Foreign Employment, 2014).
} 
correcting for attrition bias helps elevate the utility of data especially from panel surveys (OutesLeon \& Dercon, 2008). Additionally, whereas policy-researchers using longitudinal data typically rely on the relatively restrictive fixed-effects techniques, this analysis promotes the utility of random-effects techniques with adjustment for heterogeneity bias (Bell \& Jones, 2015) to enrich our understanding of the ways lives are experienced.

Given major data concerns, analyses focusing on more consistent and nationally representative data would be a more productive way forward in order to gain greater confidence in establishing the link between foreign remittance and poverty. However, the likelihood that the panel data provided from the NLSS will expand on the representation of different cross-sections diminishes over time. Particularly important for studies of foreign remittances is the ability to reduce attrition among households with migrant workers as they are likely to move. But the Government of Nepal can make a concerted effort at developing sampling schemes that ensure greater number of panel households.

\section{References}

Acharya, C. \& Leon-Gonzalez, R. (2012). Impact of remittance on poverty and inequality: A micro-simulation study for Nepal (GRIPS Discussion Paper \# 11-26). Tokyo: National Graduate Institute for Policy Studies.

Adams, R. (2005). Remittances, household expenditures, and investment in Guatemala (WB Policy Research Working Paper \#3532). Washington, DC: World Bank.

Adams, R., Cuecuecha, A., \& Page, J. (2008). The impact of remittances on poverty and inequality in Ghana (WB Policy Research Working Paper \#4732). Washington, DC: World Bank

Adams, R. (2011). Evaluating the economic impact of international remittances on developing countries using household surveys: A literature review. Journal of Development Studies, 47(6), 809-28.

Airola, J. (2007). The use of remittance income in Mexico. International Migration Review, 41(4), 850-59.

Becketti, S., Gould, W., Lillard, L., \& Welch, F. (1988). The Panel Study of Income Dynamics after Fourteen Years: An Evaluation. Journal of Labour Economics, 6, 472-92.

Bell, A., \& Jones, K. (2015). Explaining fixed effects: Random effects modeling of time-series cross-sectional and panel data. Political Science Research Methods, 13(1), 133-53.

Bhatta, S., \& Sharma, S. (2006). The determinants and consequences of transient and chronic poverty in Nepal (CPRC Working Paper \# 66). Manchester: Chronic Poverty Research Centre.

Blinder, A. S. (1973). Wage discrimination: Reduced form and structural estimates. Journal of Human Resources, 8(4), 436-55.

Brees, I. (2008). Refugee business: Strategies of work on the Thai-Burma border. Journal of Refugee Studies, 21(3), 380-97.

Carter, M., \& Barrett, C. (2006). The economics of poverty traps and persistent poverty: An asset-based approach. Journal of Development Studies, 42, 178-99.

Carter, M., \& May, J. (2001). One kind of freedom: Poverty dynamics in post-apartheid South Africa. World Development, 29, 1987-2006.

CBS. (1996). Nepal living standard survey 1995/96. Kathmandu: Central Bureau of Statistics. CBS. (2004). Nepal living standard survey report 2003/04. Kathmandu: Central Bureau of 
Statistics.

CBS. (2011b). Poverty in Nepal. Kathmandu: Central Bureau of Statistics.

CBS. (2011a). Nepal living standard survey 2010/11. Kathmandu: Central Bureau of Statistics.

Cohen, J.H. (2005). Remittance outcomes and migration: Theoretical contests, real opportunities. Studies in Comparative International Development, 40(1), 88-112.

de Haan, A. (1997). Rural-urban migration and poverty: The case of India. IDS Bulletin, 28(2), 35-47.

de Haas, H. (2007). The Impact of international migration on social and economic development in Moroccan sending regions: A review of the empirical literature (UOIMI Working Papers \#3). Oxford: University of Oxford International Migration Institute

Department of Foreign Employment. (2014). Labour migration for employment: S status report for Nepal 2013/2014. Kathmandu: Government of Nepal Department of Foreign Employment.

Du, Y., Park, A., \& Wang, S. (2005). Migration and rural poverty in China. Journal of Comparative Economics, 33, 688-709.

Ellis, F. (2003). A livelihoods approach to migration and poverty reduction. A paper commissioned by the UK Department for International Development, Contract No: CNTR 03 4890.

Fitzgerald, J., Gottschalk, P, \& Moffitt, R. (1998). The impact of attrition in the panel study of income dynamics on intergenerational analysis. Journal of Human Resources, 33(2), 300-44.

Gustafsson, B. \& Makonnen, N. (1993). Poverty and remittances in Lesotho. African Economies, 2(2), 49-73.

IOM. (2010). World migration report 2010. Geneva, Switzerland: International Organization for Migration.

Kageyama, A. (2008). Poverty alleviation by migrant remittances in Sri Lanka. South Asia Research, 28(1), 89-108.

Karki, M., \& Bohara, A. (2014). Evidence of earnings inequality based on caste in Nepal. Developing Economies, 52(3), 262-286.

Lacroix, T. (2011). Migration, rural development, poverty and food security: A comparative perspective (UOIMI Working Papers). Oxford: University of Oxford International Migration Institute

Latapi, A. (2012). Migration vs. development? The case of poverty and inequality in Mexico. Migration Letters, 9(1), 65-74.

Lokshin, M., Bontch-Osmolovski, M. \& Glinskaya, E. (2010). Work-related migration and poverty reduction in Nepal. Review of Development Economics 14(2), 323-32.

Massey, D., Arango, J., Hugo, G., Kouaouci, A., Pellegrino, A., \& Taylor, J. (1998). Worlds in motion: Understanding international migration at the end of the millennium. New York, NY: Oxford University Press.

MMN \& AMC. (2012). From our eyes: Mekong migrant reflections 2000-2012. Chiang Mai: Chiangmai University Mekong Migration on Network and Asia Migrant Centre.

Mon, M. (2010). Burmese labour migration into Thailand: Governance of migration and labour rights. Journal of the Asia Pacific Economy, 15(1), 33-44.

Mundlak, Y. (1978). Pooling of time-series and cross-section data. Econometrica, 46(1), 69-85.

Oaxaca, R. (1973). Male-female wage differentials in urban labor markets. International Economic Review, 14(3), 693-709.

Outes-Leon, I. \& Dercon, S. (2008). Survey Attrition and Attrition Bias in Young Lives. Young Lives Technical Note \# 5 . 
Rakodi, C. \& Lloyed-Jones, T. (2002). Urban livelihoods: A people-centered approach to reducing poverty. London, England: Earthscan.

Sinning, M., Hahn, M., \& Bauer, T. K. (2008). The Blinder-Oaxaca decomposition for nonlinear regression models. The Stata Journal, 8(4), 480-92.

Stark, Oded. (1991). The migration of labor. Cambridge, MA: Blackwell.

Stark, O. \& Bloom, D. (1985). The new economics of labor migration. The American Economic Review, 75(2), 173-78.

Thieme, S. (2006). Social networks and migration: Far west Nepalese labour migrants in Delhi. Munster, Germany: LIT.

Thieme, S. \& Wyss, S. (2005). Migration patterns and remittance transfer in Nepal: A case study of Sainik Basti in western Nepal. International Migration, 43(5), 59-98.

Turnell, S., Vicary, A., \& Bradford, W. (2008). Migrant-worker remittances and Burma: An economic analysis of survey results. In M. Skidmore \& T. Wilson (Eds.), Dictatorship, Disorder and Decline in Myanmar (pp. 63-86). Canberra, Australia: ANU Press.

UNCTAD. (2011). Impact of remittances on poverty in developing countries. Geneva: United Nations Conference on Trade and Development

Vargas-Lundius, R., Lanly, G., Villarreal, M., \& Osorio, M. (2008). International migration, remittances and rural development. New York: International Fund for Agricultural Development.

Vargas-Silva, C., Jha, S., \& Sugiyarto, G. (2009). Remittances in Asia: Implications for the fight against poverty and the pursuit of economic growth (ADB Economics Working Papers \# 182). Manila: Asian Development Bank.

Wagle, U. (2012). Socioeconomic implications of the increasing foreign remittance to Nepal: Evidence from the Nepal living standard survey. International Migration, 50(4), 186-207.

Wagle, U. (2015). Limited but evolving: The political economy of social protections in Nepal. Journal of Contemporary Asia, 45(1), 92-112.

Wooldridge, Jeffrey. (2009). Introductory econometrics: A modern approach. Mason, OH: Thompson South-Western.

World Bank \& DFID. (2005). Gender and social exclusion assessment: Unequal citizens: Gender, caste and ethnic exclusion in Nepal. Kathmandu: World Bank and UK Department for International Development.

World Bank, DFID, \& ADB. (2006). Nepal resilience amidst conflict: An assessment of poverty in Nepal, 1995-96 and 2003-04. Kathmandu: World Bank, UK Department for International Development, and Asian Development Bank.

World Bank. (2017). World development indicators database: Online. Washington, DC: World Bank.

YYY. (XXXX). 
Figures

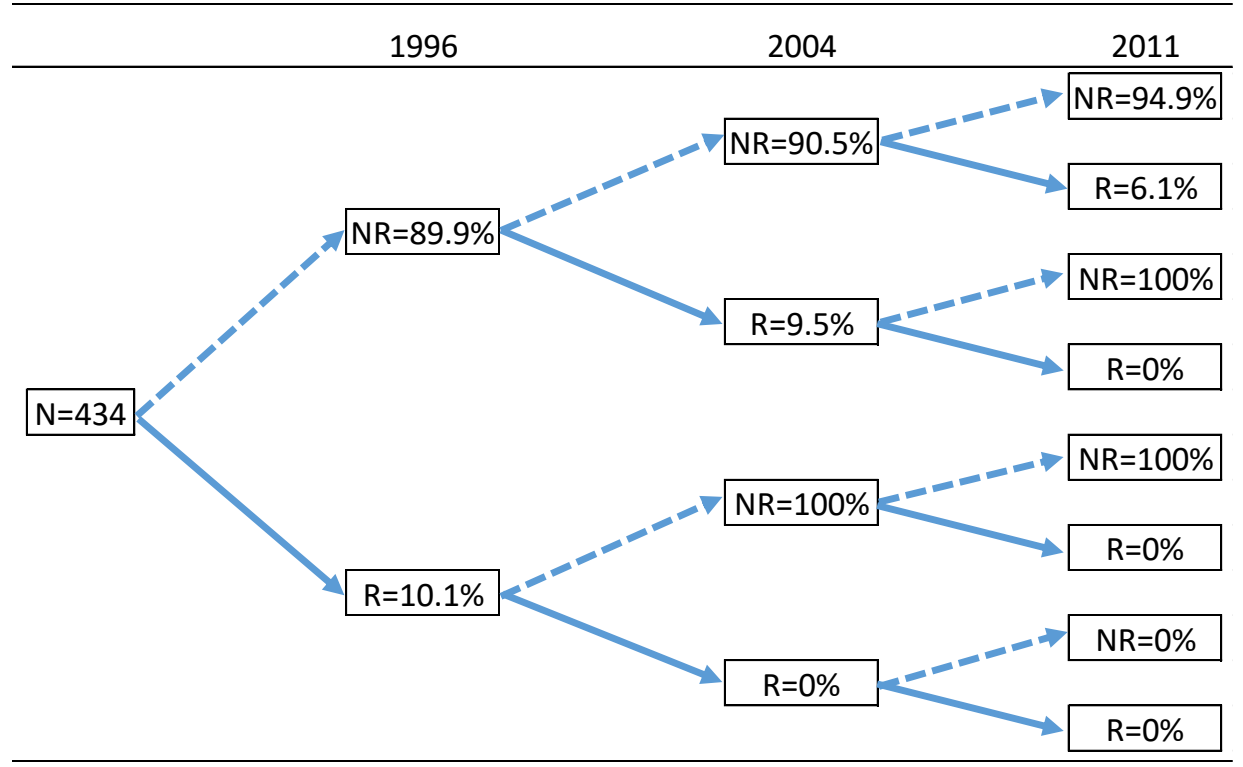

Figure 1, Temporal Status of Foreign Remittance among Households

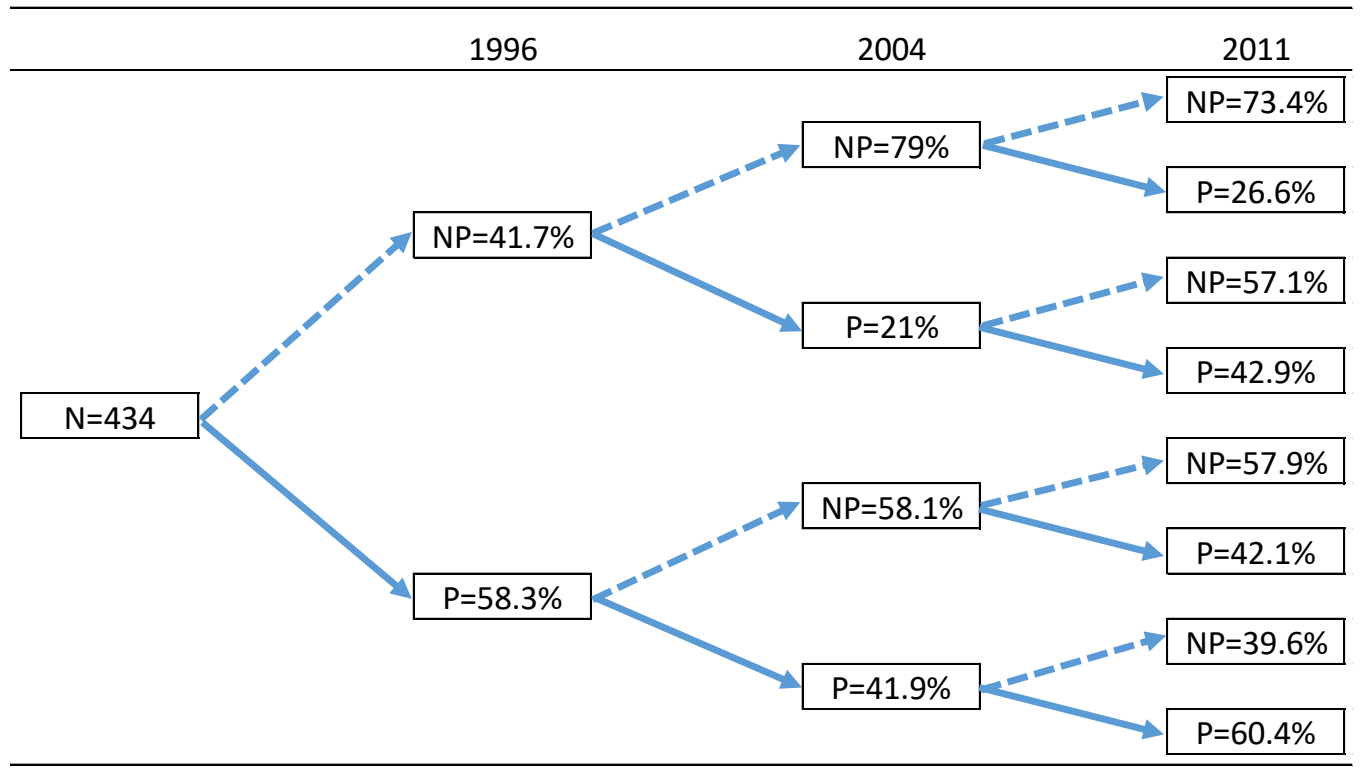

Figure 2, Temporal Status of Poverty among Households 
a. For Poor Households

Panel Sample

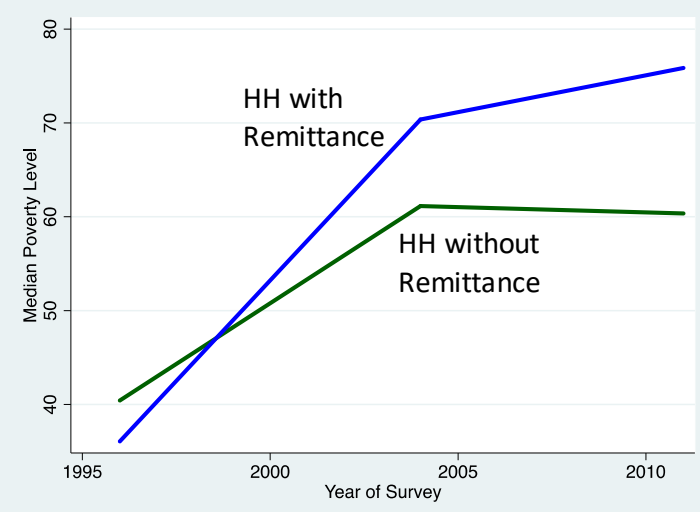

Balanced Panel

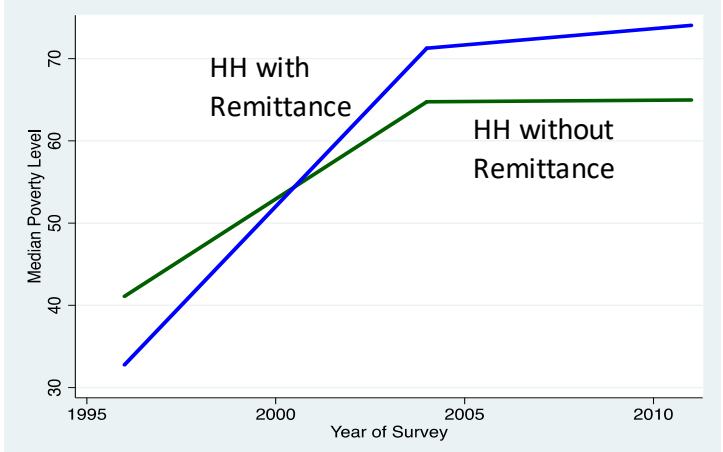

b. For Non-poor Households
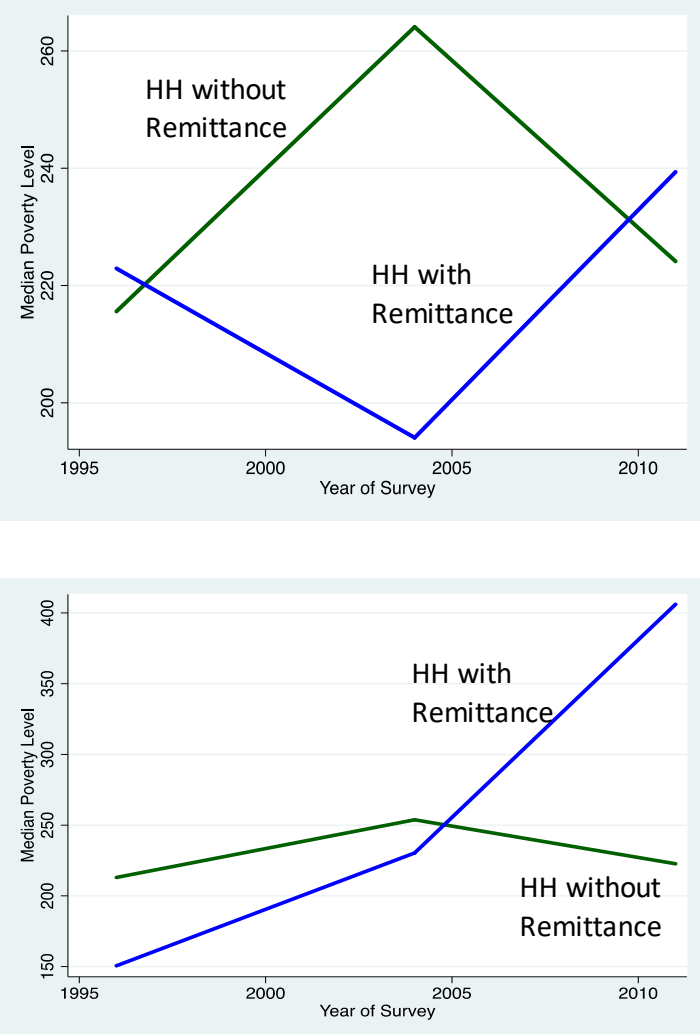

Figure 3, Median Poverty and Non-poverty Levels for HHs with and without Remittance (Poverty or non-poverty level defined as consumption relative to applicable poverty line with values below 100 indicating poverty and those above 100 indicating non-poverty) 
Tables

Table 1, Remittance Rates among Households

\begin{tabular}{|c|c|c|c|c|c|c|}
\hline \multirow{3}{*}{ Year } & \multicolumn{3}{|c|}{ Full Panel } & \multicolumn{3}{|c|}{ Balanced Panel } \\
\hline & \multirow{2}{*}{$\mathrm{N}$} & \multicolumn{2}{|c|}{$\begin{array}{c}\text { Remittance Rate } \\
(\%)\end{array}$} & \multirow{2}{*}{$\mathrm{N}$} & \multicolumn{2}{|c|}{$\begin{array}{c}\text { Remittance Rate } \\
(\%)\end{array}$} \\
\hline & & $\begin{array}{c}\text { All } \\
\text { Countries }\end{array}$ & India & & $\begin{array}{c}\text { All } \\
\text { Countries }\end{array}$ & India \\
\hline 1996 & 3376 & 10.47 & 9.17 & 432 & 10.14 & 8.99 \\
\hline 2004 & 961 & 10.30 & 3.43 & 432 & 8.53 & 3.92 \\
\hline 2011 & 1032 & 4.80 & 3.21 & 432 & 4.15 & 2.07 \\
\hline
\end{tabular}

Table 2, Poverty Among Households without and with Foreign Remittance

\begin{tabular}{lcccc}
\hline \multicolumn{1}{c}{ Samples } & \multicolumn{4}{c}{ Poverty Incidence (\%) } \\
\cline { 2 - 5 } & $\mathbf{1 9 9 6}$ & $\mathbf{2 0 0 4}$ & $\mathbf{2 0 1 1}$ & Combined \\
\hline \multicolumn{1}{c}{ Panel Sample } & & & & \\
All Households & 58.40 & 38.29 & 44.28 & 52.10 \\
Without foreign remittance & 58.18 & 38.56 & 44.69 & 51.98 \\
With foreign remittance & 60.54 & 35.63 & 36.54 & 53.29 \\
With remittance from India & 66.55 & 24.14 & 45.16 & 61.10 \\
$\quad$ Balanced Panel & & & & \\
All Households & 58.29 & 33.18 & 41.71 & 44.39 \\
Without foreign remittance & 57.44 & 33.75 & 41.83 & 44.22 \\
With foreign remittance & 65.91 & 27.03 & 38.89 & 46.46 \\
With remittance from India & 71.79 & 23.53 & 55.56 & 46.92 \\
\hline
\end{tabular}

Table 3, Poverty Status by Foreign Remittance among Balanced Panel Households across Survey Years (Values are percentages unless otherwise indicated)

\begin{tabular}{|c|c|c|c|c|c|}
\hline \multirow[b]{2}{*}{ Poor } & \multicolumn{5}{|c|}{ Foreign Remittance Received ${ }^{\mathrm{a}}(\%)$} \\
\hline & Never & In 1996 & In 2004 & In 2011 & Total \\
\hline Never & 25.07 & 15.91 & 18.92 & 38.89 & 24.19 \\
\hline In 1996 only & 19.40 & 22.73 & 21.62 & 5.56 & 19.35 \\
\hline In 2004 only & 4.78 & 2.27 & 10.81 & 5.56 & 5.07 \\
\hline In 2011 only & 9.25 & 6.82 & 10.81 & 0.00 & 8.76 \\
\hline In $1996 \& 2004$ & 9.55 & 15.91 & 2.70 & 11.11 & 9.68 \\
\hline In $1996 \& 2011$ & 13.13 & 15.91 & 21.62 & 22.22 & 14.52 \\
\hline In $2004 \& 2011$ & 2.99 & 9.09 & 5.41 & 0.00 & 3.69 \\
\hline Always & 15.82 & 11.36 & 8.11 & 16.67 & 14.75 \\
\hline $\mathrm{N}$ & 1,005 & 132 & 111 & 54 & 1,302 \\
\hline$\%$ of $\mathrm{N}$ & 77.19 & 10.14 & 8.53 & 4.15 & 100.00 \\
\hline
\end{tabular}

Note: a. No households with remittance at multiple points 
Table 4, Balanced Panel, Random Effects Logistic Regresions of Poverty Status

\begin{tabular}{|c|c|c|c|c|c|c|}
\hline \multirow{2}{*}{ Variables } & \multicolumn{2}{|c|}{ PS Model I } & \multicolumn{2}{|c|}{ PS Model II } & \multicolumn{2}{|c|}{ PS Model III } \\
\hline & Coef. & Std. Err. & Coef. & Std. Err. & Coef. & Std. Err. \\
\hline Foreign Remittance & -0.036 & 0.249 & & & & \\
\hline Foreign remittance excluding from India & & & -0.816 & $0.455 *$ & & \\
\hline Foreign remittance from India & & & 0.313 & 0.300 & & \\
\hline Amount of foreign remittance (in 2011 values) & & & & & $<-0.001$ & $<0.001$ \\
\hline \multicolumn{7}{|l|}{ Caste and ethnicity (ref.=upper caste Hindus) } \\
\hline Middle caste Hindu & 0.209 & 0.245 & 0.206 & 0.245 & 0.219 & 0.246 \\
\hline Low Caste Hindu & 0.408 & 0.255 & 0.446 & $0.256 *$ & 0.406 & 0.255 \\
\hline Newar & 0.344 & 0.382 & 0.345 & 0.383 & 0.320 & 0.382 \\
\hline Janajati & 0.664 & $0.199 * * *$ & 0.695 & $0.200 * * *$ & 0.660 & $0.199 * * *$ \\
\hline Muslim and others & 0.089 & 0.383 & 0.126 & 0.382 & 0.140 & 0.384 \\
\hline Urban areas & -1.133 & $0.366 * * *$ & -1.138 & $0.367 * * *$ & -1.114 & $0.367 * * *$ \\
\hline \multicolumn{7}{|l|}{ Development region (ref.=eastern) } \\
\hline Central & 0.331 & $0.191 *$ & 0.329 & $0.191 *$ & 0.334 & $0.191 *$ \\
\hline Western & -0.226 & 0.230 & -0.242 & 0.230 & -0.221 & 0.230 \\
\hline Mid-western & -0.041 & 0.265 & -0.051 & 0.265 & -0.053 & 0.265 \\
\hline Far-western & 1.018 & $0.316 * * *$ & 1.008 & $0.316^{* * *}$ & 1.006 & $0.316^{* * *}$ \\
\hline \multicolumn{7}{|l|}{ Econological belt (ref.=mountains) } \\
\hline Hills & 0.605 & $0.243 * *$ & 0.625 & $0.243 * * *$ & 0.604 & $0.243 * *$ \\
\hline Terai & -0.092 & 0.236 & -0.086 & 0.236 & -0.092 & 0.237 \\
\hline Household size & -0.014 & 0.052 & -0.013 & 0.052 & -0.012 & 0.052 \\
\hline \# of $\mathrm{HH}$ members under 18 & 0.163 & $0.074 * *$ & 0.164 & $0.074 * *$ & 0.166 & $0.074 * *$ \\
\hline HH head--Sex: Female & 0.012 & 0.222 & 0.001 & 0.223 & 0.047 & 0.223 \\
\hline HH head--Age & -0.021 & 0.031 & -0.019 & 0.031 & -0.020 & 0.031 \\
\hline HH head--Age squared & $<0.000$ & $<0.000$ & $<0.000$ & $<0.000$ & $<0.000$ & $<0.000$ \\
\hline HH head--Can read & 0.142 & 0.170 & 0.128 & 0.170 & 0.123 & 0.170 \\
\hline HH head--Education & -0.060 & $0.024 * *$ & -0.059 & $0.024 * *$ & -0.059 & $0.024 * *$ \\
\hline \multicolumn{7}{|l|}{ HH head--Marital status (ref.=married) } \\
\hline Widowed/divorced/separated & 0.253 & 0.236 & 0.260 & 0.237 & 0.227 & 0.237 \\
\hline Never married & 0.483 & 0.633 & 0.472 & 0.636 & 0.480 & 0.633 \\
\hline \multicolumn{7}{|l|}{ HH Head--Occupation (ref.=others) } \\
\hline Administrative, Professional \& Technical & -0.490 & 0.422 & -0.469 & 0.422 & -0.499 & 0.421 \\
\hline Sales & 0.131 & 0.339 & 0.144 & 0.340 & 0.129 & 0.339 \\
\hline Agriculture \& Forestry & 0.247 & 0.210 & 0.261 & 0.210 & 0.253 & 0.210 \\
\hline Production & -0.305 & 0.298 & -0.285 & 0.298 & -0.291 & 0.298 \\
\hline Property per capita (Log) & -0.348 & $0.055 * * *$ & -0.341 & $0.055^{* * *}$ & -0.344 & $0.055 * * *$ \\
\hline _Constant & 3.180 & $0.970 * * *$ & 3.041 & $0.971 * * *$ & 3.080 & $0.972 * * *$ \\
\hline Fraction of poor and non-poor accurately predicted & 0.671 & & 0.669 & & 0.674 & \\
\hline
\end{tabular}

Note: ${ }^{*} \mathrm{P}<0.10 ;{ }^{* *} \mathrm{P}<0.05 ;{ }^{* * *} \mathrm{P}<0.01$ 
Table 5, Balanced Panel, Random Effects (MLE) Regressions of Non-poverty Level (unweighted)

\begin{tabular}{|c|c|c|c|c|c|c|}
\hline \multirow[b]{2}{*}{ Variables } & \multicolumn{2}{|c|}{ NPL Model I } & \multicolumn{2}{|c|}{ NPL Model II } & \multicolumn{2}{|c|}{ NPL Model III } \\
\hline & Coef. & Std. Err. & Coef. & Std. Err. & Coef. & Std. Err. \\
\hline Foreign Remittance & 111.714 & $64.642 *$ & & & & \\
\hline Foreign remittance excluding from India & & & 326.786 & $106.475 * * *$ & & \\
\hline Foreign remittance from India & & & -2.101 & 78.539 & & \\
\hline Amount of foreign remittance (in 2011 values) & & & & & 0.004 & $<0.001 * * *$ \\
\hline \multicolumn{7}{|l|}{ Caste and ethnicity (ref.=upper caste Hindus) } \\
\hline Middle caste Hindu & 38.422 & 60.242 & 41.467 & 60.105 & -1.494 & 50.047 \\
\hline Low Caste Hindu & 67.927 & 62.752 & 57.909 & 62.722 & 18.921 & 52.143 \\
\hline Newar & -103.982 & 81.071 & -94.724 & 80.954 & -35.726 & 67.266 \\
\hline Janajati & 57.145 & 48.498 & 49.786 & 48.465 & 2.360 & 40.317 \\
\hline Muslim and others & -6.434 & 96.932 & -13.322 & 96.731 & -61.939 & 80.508 \\
\hline Urban areas & 410.064 & $76.930 * * *$ & 404.019 & $76.777^{* * *}$ & 273.886 & $64.120 * * *$ \\
\hline \multicolumn{7}{|l|}{ Development region (ref.=eastern) } \\
\hline Central & -31.795 & 46.810 & -29.228 & 46.705 & -16.422 & 38.839 \\
\hline Western & 91.486 & 56.200 & 97.071 & $56.105 *$ & 62.957 & 46.598 \\
\hline Mid-western & -32.637 & 66.814 & -28.826 & 66.666 & -9.591 & 55.479 \\
\hline Far-western & -80.003 & 75.935 & -75.768 & 75.766 & -47.605 & 63.065 \\
\hline \multicolumn{7}{|l|}{ Econological belt (ref.=mountains) } \\
\hline Hills & -23.061 & 60.374 & -28.891 & 60.269 & -18.715 & 50.130 \\
\hline Terai & 22.415 & 59.407 & 19.685 & 59.271 & 32.491 & 49.322 \\
\hline Household size & -3.580 & 13.299 & -3.600 & 13.266 & -7.373 & 11.034 \\
\hline \# of $\mathrm{HH}$ members under 18 & -7.894 & 18.734 & -7.952 & 18.688 & -3.774 & 15.555 \\
\hline HH head--Sex: Female & -3.917 & 56.078 & 2.221 & 55.992 & -93.716 & $46.597 * *$ \\
\hline HH head--Age & -4.100 & 8.005 & -4.365 & 7.986 & 4.254 & 6.656 \\
\hline HH head--Age squared & 0.003 & 0.079 & 0.006 & 0.079 & -0.072 & 0.066 \\
\hline HH head--Can read & -16.460 & 44.552 & -12.732 & 44.467 & -11.657 & 36.804 \\
\hline HH head--Education & 0.891 & 5.585 & 0.445 & 5.574 & -3.169 & 4.638 \\
\hline \multicolumn{7}{|l|}{ HH head--Marital status (ref.=married) } \\
\hline Widowed/divorced/separated & -59.883 & 60.407 & -63.542 & 60.275 & -17.715 & 50.088 \\
\hline Never married & 419.623 & $150.687 * * *$ & 426.927 & $150.343 * * *$ & 505.826 & $125.164 * * *$ \\
\hline \multicolumn{7}{|l|}{ HH Head--Occupation (ref.=others) } \\
\hline Administrative, Professional \& Technical & 42.564 & 89.216 & 37.298 & 89.020 & 66.934 & 74.025 \\
\hline Sales & -28.853 & 81.004 & -34.218 & 80.832 & -22.494 & 67.254 \\
\hline Agriculture \& Forestry & -11.128 & 53.295 & -15.765 & 53.195 & -53.378 & 44.286 \\
\hline Production & -99.033 & 73.868 & -103.775 & 73.709 & -131.472 & $61.347 * *$ \\
\hline Property per capita (Log) & 77.980 & $12.895 * * *$ & 75.020 & $12.916 * * *$ & 69.858 & $10.709 * * *$ \\
\hline _Constant & -455.094 & $246.117 *$ & -415.770 & $245.998 *$ & -418.916 & $204.338 * *$ \\
\hline LR Chi-Sq & 174 & & 180 & & 658 & \\
\hline DF & 27 & & 28 & & 27 & \\
\hline $\mathrm{P}>\mathrm{Chi}-\mathrm{Sq}$ & 0 & & 0 & & 0 & \\
\hline
\end{tabular}

Note: ${ }^{*} \mathrm{P}<0.10$; ** $\mathrm{P}<0.05 ; * * * \mathrm{P}<0.01$ 
Table 6, Balanced Panel, Random Effects (MLE) Regressions of Non-poverty Level (weighted for attrition bias)

\begin{tabular}{|c|c|c|c|c|c|c|}
\hline \multirow[b]{2}{*}{ Variables } & \multicolumn{2}{|c|}{ NPL Model IV } & \multicolumn{2}{|c|}{ NPL Model V } & \multicolumn{2}{|c|}{ NPL Model VI } \\
\hline & Coef. & Std. Err. & Coef. & Std. Err. & Coef. & Std. Err. \\
\hline Foreign Remittance & 147.229 & $61.605 * *$ & & & & \\
\hline Foreign remittance excluding from India & & & 446.122 & $101.807 * * *$ & & \\
\hline Foreign remittance from India & & & -8.036 & 74.443 & & \\
\hline Amount of foreign remittance (in 2011 values) & & & & & 0.005 & $<0.001 * * *$ \\
\hline \multicolumn{7}{|l|}{ Caste and ethnicity (ref.=upper caste Hindus) } \\
\hline Middle caste Hindu & 49.885 & 54.516 & 55.343 & 54.278 & -2.173 & 41.814 \\
\hline Low Caste Hindu & 87.904 & 63.113 & 75.182 & 62.909 & 20.675 & 48.415 \\
\hline Newar & -118.958 & 82.245 & -105.530 & 81.938 & -18.799 & 63.025 \\
\hline Janajati & 84.436 & $47.680 *$ & 74.211 & 47.536 & 4.329 & 36.618 \\
\hline Muslim and others & 2.953 & 91.774 & -7.048 & 91.381 & -49.354 & 70.350 \\
\hline Urban areas & 475.266 & $76.552 * * *$ & 466.869 & $76.224 * * *$ & 274.477 & $59.007 * * *$ \\
\hline \multicolumn{7}{|l|}{ Development region (ref.=eastern) } \\
\hline Central & -47.103 & 45.155 & -42.816 & 44.957 & -28.706 & 34.566 \\
\hline Western & 101.789 & $55.589 *$ & 109.889 & $55.370 * *$ & 54.471 & 42.551 \\
\hline Mid-western & -33.735 & 64.461 & -28.805 & 64.170 & -12.455 & 49.402 \\
\hline Far-western & -87.466 & 72.947 & -81.393 & 72.621 & -53.160 & 55.917 \\
\hline \multicolumn{7}{|l|}{ Econological belt (ref.=mountains) } \\
\hline Hills & -28.836 & 57.349 & -36.699 & 57.118 & -23.114 & 43.950 \\
\hline Terai & 18.785 & 56.588 & 15.339 & 56.328 & 33.835 & 43.359 \\
\hline Household size & -5.531 & 12.759 & -5.378 & 12.699 & -9.139 & 9.774 \\
\hline \# of $\mathrm{HH}$ members under 18 & -6.851 & 18.013 & -7.353 & 17.928 & -2.190 & 13.805 \\
\hline HH head--Sex: Female & 21.448 & 54.762 & 28.859 & 54.540 & -90.348 & $42.032 * *$ \\
\hline HH head--Age & -7.351 & 7.911 & -7.519 & 7.874 & 4.478 & 6.075 \\
\hline HH head--Age squared & 0.036 & 0.079 & 0.039 & 0.078 & -0.070 & 0.061 \\
\hline HH head--Can read & -15.829 & 43.260 & -9.930 & 43.085 & -11.724 & 32.984 \\
\hline HH head--Education & 5.069 & 5.454 & 4.488 & 5.430 & -0.045 & 4.181 \\
\hline \multicolumn{7}{|l|}{ HH head--Marital status (ref.=married) } \\
\hline Widowed/divorced/separated & -59.025 & 58.378 & -64.756 & 58.122 & -9.418 & 44.693 \\
\hline Never married & 395.869 & $163.169 * *$ & 407.841 & $162.430 * *$ & 509.633 & $125.096 * * *$ \\
\hline \multicolumn{7}{|l|}{ HH Head--Occupation (ref.=others) } \\
\hline Administrative, Professional \& Technical & 52.237 & 88.839 & 43.935 & 88.448 & 77.620 & 68.026 \\
\hline Sales & -22.963 & 81.936 & -32.664 & 81.592 & -23.010 & 62.788 \\
\hline Agriculture \& Forestry & 18.627 & 53.778 & 11.197 & 53.562 & -45.585 & 41.265 \\
\hline Production & -76.161 & 73.507 & -85.003 & 73.198 & -117.118 & $56.351 * *$ \\
\hline Property per capita (Log) & 75.726 & $12.653 * * *$ & 71.424 & $12.648 * * *$ & 64.368 & $9.701 * * *$ \\
\hline _Constant & -420.818 & $239.786 *$ & -368.549 & 239.075 & -381.321 & $183.753 * *$ \\
\hline LR Chi-Sq & 194 & & 208 & & 941 & \\
\hline DF & 27 & & 28 & & 27 & \\
\hline $\mathrm{P}>\mathrm{Chi}-\mathrm{Sq}$ & 0 & & 0 & & 0 & \\
\hline
\end{tabular}

Note: $* \mathrm{P}<0.10 ; * * \mathrm{P}<0.05 ; * * * \mathrm{P}<0.01$ 
Table 7, Balanced Panel, Random Effects Regressions of Non-poverty Level and Poverty Status

(with adjustment for heterogeneity bias)

\begin{tabular}{|c|c|c|c|c|}
\hline \multirow[b]{2}{*}{ Variables } & \multicolumn{2}{|c|}{ NPL Model VII } & \multicolumn{2}{|c|}{ PS Model IV } \\
\hline & Coef. & Std. Err. & Coef. & Std. Err. \\
\hline Annual average foreign remittance, NRS & 0.004 & $<0.001 * * *$ & $<-0.001$ & $<0.001$ \\
\hline Mean differenced foreign remittance, NRS & 0.006 & $<0.001 * * *$ & $<-0.001$ & $<0.001 * * *$ \\
\hline \multicolumn{5}{|l|}{ Caste and ethnicity (ref.=upper caste Hindus) } \\
\hline Middle caste Hindu & 20.889 & 49.913 & 0.062 & 0.255 \\
\hline Low Caste Hindu & 45.984 & 52.094 & 0.239 & 0.265 \\
\hline Newar & -27.248 & 66.778 & 0.248 & 0.396 \\
\hline Janajati & 18.891 & 40.178 & 0.575 & $0.206 * * *$ \\
\hline Muslim and others & -36.031 & 80.100 & -0.041 & 0.397 \\
\hline Urban areas & 257.959 & $63.728 * * *$ & -1.031 & $0.378 * * *$ \\
\hline \multicolumn{5}{|l|}{ Development region (ref.=eastern) } \\
\hline Central & -15.807 & 38.542 & 0.344 & $0.198 *$ \\
\hline Western & 60.297 & 46.245 & -0.219 & 0.238 \\
\hline Mid-western & -0.172 & 55.095 & -0.091 & 0.274 \\
\hline Far-western & -45.225 & 62.585 & 1.055 & $0.328 * * *$ \\
\hline \multicolumn{5}{|l|}{ Econological belt (ref.=mountains) } \\
\hline Hills & -28.522 & 49.795 & 0.688 & $0.253 * * *$ \\
\hline Terai & 26.366 & 48.964 & -0.053 & 0.245 \\
\hline Household size & -8.929 & 10.955 & -0.002 & 0.054 \\
\hline \# of $\mathrm{HH}$ members under 18 & -4.554 & 15.436 & 0.173 & $0.076 * *$ \\
\hline HH head--Sex: Female & -72.593 & 46.479 & -0.114 & 0.231 \\
\hline HH head--Age & 5.469 & 6.610 & -0.032 & 0.032 \\
\hline HH head--Age squared & -0.077 & 0.065 & 0.000 & 0.000 \\
\hline HH head--Can read & 79.307 & $41.765 *$ & -0.460 & $0.204 * *$ \\
\hline HH head--Education & -7.282 & 4.693 & -0.035 & 0.024 \\
\hline \multicolumn{5}{|l|}{ HH head--Marital status (ref.=married) } \\
\hline Widowed/divorced/separated & -24.822 & 49.730 & 0.280 & 0.242 \\
\hline Never married & 503.034 & $124.207 * * *$ & 0.517 & 0.668 \\
\hline \multicolumn{5}{|l|}{ HH Head--Occupation (ref.=others) } \\
\hline Administrative, Professional \& Technical & 71.669 & 73.466 & -0.518 & 0.428 \\
\hline Sales & -18.207 & 66.746 & 0.095 & 0.346 \\
\hline Agriculture \& Forestry & -51.825 & 43.949 & 0.244 & 0.215 \\
\hline Production & -126.564 & $60.887 * *$ & -0.351 & 0.306 \\
\hline Property per capita (Log) & 82.580 & $10.998 * * *$ & -0.428 & $0.060 * * *$ \\
\hline _Constant & -806.874 & $220.415 * * *$ & 5.651 & $1.119^{* * *}$ \\
\hline LR or Wald Chi-Sq & 678 & & 170 & \\
\hline DF & 28 & & 28 & \\
\hline $\mathrm{P}>\mathrm{Chi}-\mathrm{Sq}$ & 0 & & 0 & \\
\hline
\end{tabular}

Note: * $\mathrm{P}<0.10 ; * * \mathrm{P}<0.05 ; * * * \mathrm{P}<0.01$

Table 8, Binder-Oaxaca Decomposition of Non-poverty Level by Remittance Status

\begin{tabular}{lcc}
\hline \multicolumn{1}{c}{ Remittance Status } & $\begin{array}{c}\text { \% Difference in } \\
\text { Variation Explained } \\
\text { by Characteristics }\end{array}$ & $\begin{array}{c}\text { \% Difference in } \\
\text { Variation Explained } \\
\text { by Remittance Status }\end{array}$ \\
\hline With foreign remittance & 55.524 & 44.476 \\
With foreign remittance from India & 50.587 & 49.413 \\
With foreign remittance from countries other than India & 51.630 & 48.370 \\
\hline
\end{tabular}

